bicarbonate (or sodium hydroxide) and severe metabolic alkalosis with hydrochloric acid. When acid or alkali is administered therapeutically in $50-100-\mathrm{mmol}$ quantities it is rational to express their impact on the patient in the same way.

There are two less familiar ways of expressing acidity within the SI. The most scientifically rigorous is to express acidity in terms of the chemical potential of $\mathrm{H}$ ion; the SI unit for energy, the joule, is used for this purpose so that normal arterial plasma acidity becomes -44.23 to $-43.76 \mathrm{~kJ} / \mathrm{mol}^{3}{ }^{3}$ One can easily imagine that this unit would not be acceptable in ordinary medical use. The fourth term for acidity is the concentration of free $\mathrm{H}$ ions in $\mathrm{nmol} / \mathrm{l}$ derived from $\mathrm{pH}$ in a stricter manner than indicated above. Readers seeking more information about this complex matter are referred to Professor Siggaard-Andersen's contributions cited below. ${ }^{1:}$

P J N HOWORTH

Department of Chemical Pathology, King's College Hospital,

London SE5

Siggaard-Andersen, $O$, Scandinavian fournal of Clinical and Laboratory Investigation, 1977, 37, suppl 146, p 7.
Worthley, L I G, British fournal of Anaesthesia, 1977, 49, 811 .

Siggaard-Andersen, O, Blood pH, Gases, and Electro ytes, ed R A Durst, p 1. Washington, DC, Nation Bureau of Standards Special Publication No 450 1977.

\section{Tetrabenazine in Huntington's chorea}

SIR,-We have just come across a most remarkable misquotation in the paper on this subject by Drs C $\mathrm{H}$ Hawkes and $\mathrm{C} \mathrm{H}$ Nourse (28 May, p 1391).

It is said there that we "have expressed reservations about tetrabenazine in Huntington's chorea, suggesting that the risks of depression and drug-induced Parkinsonism outweigh the advantages of its antichoreic action." We made no such point in our paper but on the contrary said that depression is common in Huntington's chorea and it is difficult to be certain whether it is caused by the drug. Parkinsonism was also not noted in our series. We suggested instead that postural hypotension and dysphagia were the serious side effects which require careful supervision.

C Y HuANG

C ElliotT

Lidcombe Hospital,

New South Wales

Huang, C Y, et al, Medical fournal of Australia

\section{Vertigo in children}

SIR,-I should like to mention another possible cause of vertigo in children which was omitted from your leading article $(5$ November, p 1173)-namely, Menière's disease. I fully appreciate that this is extremely rare in childhood, but it is important because of the potential damage to hearing.

At the age of $7 \mathrm{I}$ suffered a number of severe attacks of vertigo and subsequently became deaf in one ear. By the time this was brought to medical attention there was profound hearing loss, and anyway probably nothing much could have been done then At the age of 21 tinnitus and distortion of hearing appeared in the other ear, but vertigo did not appear until seven years later. It was only then fully appreciated that I had bilateral Menière's disease. I was not much encouraged by your leading article on "Surgery for Menière's disease" (15 January, p 124), but did have an endolymphatic sac drainage operation in March, which has been of enormous benefit. It has restored my hearing from $30-50 \mathrm{~dB}$ to within normal limits and abolished vertigo.

It is for this reason that I would urge colleagues presented with vertiginous children to examine the hearing also in order not to miss a condition which may now be helped in certain cases. Also, it is all too easy to dismiss vertigo as "benign," but during my childhood attacks I narrowly escaped injury on more than one occasion. Regarding treatment of other causes of vertigo, sedatives and antiemetics can do a great deal to alleviate the distress of persistent nausea and vomiting while the condition lasts.

Patricia M Sarter

Nantwich, Cheshire

\section{Vertigo and the pill}

SIR,-I have read with interest your leading article on the incidence of vertigo in children (5 November, p 1173)

My experience as an otolaryngologist has led me to believe that there are many causes of vertigo, especially in young people, which have not been recognised so far. The common causes of labyrinthine vertigo such as Menière's disease or labyrinthitis usually occur in the older age groups, but in my personal practice I have met with an increasing number of young women who have suffered from true vertigo. Examination of their respiratory tract has not shown evidence of disease in the ears, nor has there been very much in the way of deafness or disorder of labyrinthine function as shown on an electronystagmograph.

There has been one common thread in all these patients and that is that most of them are young women in their 20 s and 30 s taking a contraceptive pill. They have often related the onset of the symptoms to the time when they began taking the pill. In many cases I have persuaded the patient to discontinue the pill and perhaps adopt an alternative method of contraception and the incidence of vertigo has subsided. An attempt was made to gain the co-operation of a family planning clinic to send patients along who are on the pill with a view to testing their hearing as well as their labyrinthine function, but unfortunately most of them were unwilling to submit to such an investigation and it had to be abandoned.

Liverpool

J SiEgLER

\section{A dangerous kitchen tool}

SIR,-We wish to draw attention to a possible danger from the use of the currently popular and reputable types of freezer knife. These are used to cut frozen foods and to chip away ice, when the knife is held as a dagger. As can be seen from the illustration, this exposes the hand to injury if the grip slips down on to the blade. A housewife aged 53 attended this department with a laceration of the little finger of the right hand sustained in this way which severed both flexor tendons and one digital nerve.

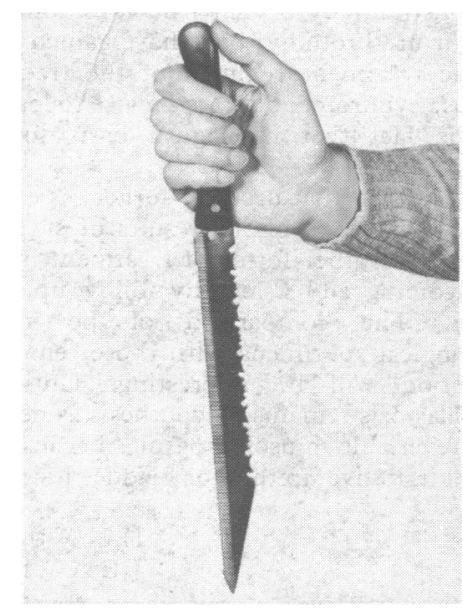

This would appear to be an unacceptable risk and the knife should be either withdrawn or modified to embody a guard.

ANDREW K MARSDEN MiCHAEL W Flowers

Accident and Emergency Department,

General Infirmary,

Leeds

Anti-e and vertical transmission of hepatitis $B$ surface antigen

SIR,-OKada and his colleagues ${ }^{1}$ provided evidence that hepatitis $\mathrm{Be}$ antigen $(\mathrm{HBeAg})$ may be used to predict transmission, and anti-HBe the absence of transmission, of hepatitis $B$ virus from asymptomatic carrier mothers to children. The same group of workers" found that $\mathrm{HBsAg}$-specific DNA polymerase activity was invariably present in serum samples of asymptomatic carriers containing $\mathrm{HBeAg}$ but was not detectable in serum samples containing anti-HBe. The lack of infectivity of anti-HBe-containing $\mathrm{HBsAg}$ positive serum has, however, recently been questioned. Berquist and his colleagues ${ }^{3}$ were able to produce experimental hepatitis $\mathrm{B}$ in a chimpanzee by inoculating it with anti-HBecontaining $\mathrm{HBsAg}$-positive human serum.

In Glasgow during the last 18 months we have followed up eight asymptomatic carrier mothers and their eight children over a period ranging from three to 13 months.

Of these, two babies, both male, developed HBs-antigenaemia at the age of 3 months. One baby born to a mother whose serum contained HBeAg had no clinical or biochemical evidence of hepatitis and later became a persistent $\mathrm{HBsAg}$ carrier. The other baby born to a mother whose serum contained anti-HBe at the time of delivery subsequently developed acute icteric hepatitis with peak serum bilirubin at $116 \mu \mathrm{mol} / 1$, peak aspartic (AST) and alanine (ALT) aminotransferases at 3945 and $1830 \mathrm{U} / 1$ respectively. He made an uneventful clinical and biochemical recovery and cleared the circulating antigen 62 days after its initial appearance. Three months later antibody to HBsAg (anti-HBs) was demonstrated in his serum. The most probable source of this infection would appear to be the mother (as the baby was subtype ay, mother subtype ay, and father negative for both antigen and antibody). Gerety ${ }^{4}$ also reported a similar case of hepatitis $B$ in an infant born to an asymptomatic carrier mother whose serum contained anti-HBe. Our evidence and that of Gerety indicate that carriers of hepatitis B surface antigen who are positive for anti-HBe cannot be regarded as totally non-infectious, at least in the vertical transmission situation, although the probability of an anti-HBe-positive mother transmitting the infection to her offspring may be 
much less than that of a $\mathrm{HBeAg}$-positive mother. It is of particular interest that the child born to our anti-HBe-positive carrier mother and the case reported previously both developed an acute infection, in contrast to children of HBeAGpositive mothers, who became asymptomatic carriers. The only evidence of hepatitis B infection in these children after elimination of antigen was the presence of antibody.

It is thus necessary to perform serial screening on children born to $\mathrm{HBsAg}$-positive mothers, for anti-HBs as well as $\mathrm{HBsAg}$, in any study of e/anti-e as a possible marker for vertical transmission.

\section{A K R ChaUdhur}

\section{Department of Infectious Diseases, \\ Gelvidere}

Regional Virus Laboratory Ruchill Hospital, Ruchill Hos
Glasgow:

\section{E A C Follet}

Department of Bacteriology,

C J Burrell

\section{Okada, K, et al, New England fournal of Medicine, 1976, 294, 746 . \\ Mayumi, M, Miawkawa, Y, New England fournal of Medicine, 1976, 295, 171. \\ Berquist, K R, et al, Lancet, 1976, 1, 1026. Gerety, R J, New England fournal of Medicine, 1976}

\section{Finger clubbing}

SIR,-Your leading article on finger clubbing (24 September, p 785) does not mention one very interesting facet of this syndrome-its reversibility when it is caused by chronic pulmonary disease, as the following case report illustrates.

The patient is a woman now 66 years old. She has been a very heavy smoker since I first met her in 1948, smoking over 60 mentholated cigarettes a day. Over the years she developed increasing cough and constantly purulent sputum. She gradually developed typical clubbing of the fingers and toes, with widening of the terminal phalanges and curvature of the nails in both the transverse and longitudinal directions. She stopped smoking immediately before a radical mastectomy in 1972 and has not resumed the habit since that time. When last seen in June 1977 her cough was minimal and there was no evidence of finger clubbing.

M G JACOBY

Patchogue,
New York

\section{Research priorities}

SIR,-I doubt if many will dare to comment on this topic (leading article, 5 November, p 1174), because it is known to be the prerogative of the "big battalions." Although we are in a technological era in which one would expect a few centres of excellence to produce the most rapid results, the people who work in such institutions tend to recognise only the feasibility of their own particular bent. Indeed, research workers of ten reach the stage when their main objective is self-justification in order to keep either family stability or simply their own prestige.

Both medicine and the economic situation are dynamic changing situations which have to be subject to feedback information and revitalisation with new ideas from the periphery. Individuality must not be stifled. Five-year plans and appointments are important. Research priorities have tended to be based on emotive issues or on the demands of medical or social pressure groups, as with the feeling that one must contribute to cancer, leukaemia, or multiple sclerosis. In fact virus biochemistry is probably not yet sufficiently mature. There has to be an appraisal of scientific advances or vogues in terms of their practical value by people working in a wider medical context. However, in these days of super-specialisation there are few who can combine a knowledge of the laboratory bench and all the technical nuances with real medical perspective.

There are more sobering thoughts, such as that the rift between medicine and pathology has resulted in a burial of many contributions from the latter in unread texts. Worse still, the really good advice to stop smoking, drinking, and eating to excess and to exercise more will always go unheeded by the majority of the public.

Newcastle upon Tyne

E N WARDLE

SIR,-Your leading article on research priorities ( 5 November, $p$ 1174) omits one important factor concerning waste of money when little is available. Not only is money wasted on "poor quality so-called research projects," but the amount of duplication of research also wastes scarce funds.

If everyone before starting on a research project were to spend a couple of hours in a reasonable medical library finding out whether this or a closely related project had been done before it could result in a considerable reduction in this wastage and the money thus saved could be used in a positive manner. It could even be that the meagre funds prove not to be so inadequate after all if this factor could be eliminated or reduced.

Fiona Mackay Picken St George's Library

St George's Hospital Medical School,

Sondon SW'17
Lond

\section{Frusemide-induced pancreatitis}

SIR,-There appeared in your journal in $1975^{1}$ a report of frusemide-induced pancreatitis. Since our group uses large amounts of frusemide intravenously in an intensive care unit, at that time we studied 20 patients who received more than $250 \mathrm{mg}$ of frusemide as a bolus. In no instance was it possible to demonstrate a rise in the serum amylase activity after drug administration. For that reason these studies were discontinued. However in a three-week period in March 1977 we observed three patients who developed pancreatitis following intravenous frusemide administration. All three patients were Black male adults with a history of chronic alcoholism. In brief, their clinical histories were as follows.

(1) A 40-year-old man presented in diabetic stupor and renal failure. Pre-frusemide serum amylase activity was $400 \mathrm{IU} .1$. He was given 500 $\mathrm{mg}$ frusemide and $12 \mathrm{~h}$ later was noted to have marked abdominal tenderness; the serum amylase activity was 3200 IU 1 . A plain abdominal radiograph showed marked pancreatic calcification. The patient died in renal failure $48 \mathrm{~h}$ later.

(2) A 56-year-old man presented in gross congestive cardiac failure, for which $250 \mathrm{mg}$ frusemide was administered. The serum amylase level rose from $210 \mathrm{IU} / 1$ to $2700 \mathrm{IU} / 18 \mathrm{~h}$ after frusemide administration in association with severe abdominal pain. The patient was treated conservatively and recovered.

(3) A 49-year-old man presented with haematemesis and melaena due to bleeding oesophageal varices. Frusemide $(250 \mathrm{mg})$ was administered for anuria. Eighteen hours later the patient complained of abdominal pain; the serum amylase activity was found to be 3900 IU / 1 compared with 460 IU 1 pre-frusemide. The patient ultimately recovered.

In these three patients the pre-frusemide serum amylase values were obtained by recovering serum from the routine blood samples taken on admission to the intensive care unit. Since seeing them we have studied a further 15 patients, with no history of alcoholism and/or pancreatic disease or diabetes, who received frusemide. A prefrusemide serum amylase estimation was made, followed by hourly estimations for $6 \mathrm{~h}$ and either a $13-\mathrm{h}$ or $24-\mathrm{h}$ level. In none of these patients could we demonstrate a significant rise in the serum amylase activity.

We conclude that frusemide in high dosage is unlikely to produce pancreatitis in the vast majority of patients and that this potential risk does not represent a contraindication to the use of frusemide. Possibly, however, this drug should be used with caution in the presence of acute or chronic pancreatic disease.

N BUCHANAN R D CANE

Intensive Care Unit, Johannesburg, South Africa

Jones, $\mathrm{P}$ E, and Oelbaum, $\mathrm{M} \mathrm{H}$, British Medical Fournal, 1975, 1, 133.

\section{Tietze's syndrome}

SIR,-I was interested in Dr G V Gill's report (20 August, p 499) and Dr M Härkönen's letter (22 October, p 1087) concerning Tietze's disease. Like many diseases, once one becomes aware of it and starts to look for it, one finds it. In general practice I see one or two cases most years.

It can, indeed, be resistant to oral antiinflammatory drugs and to physiotherapy and may persist many months. I have not tried lignocaine and corticosteroid injections but must do so, evidently. Perhaps methylprednisolone acetate would be the most effective, with its more prolonged action, for it seems to work better in other tissue injections.

C W F MCKEAN

Leominster, Herefordshire

\section{Teaching general practice}

SIR,-The first column of your leading article on this subject (22 October, p 1042) explains why general practice is difficult to teach in an academic setting and why some academic institutions may resist its introduction into the curriculum on equal terms with other disciplines. In it you appear impartial and perceptive.

The second column presents a contrast. In it you seem to imply (1) that the proper teaching of general practice in such a setting is not consistent with "a major clinical commitment" on the part of the teachers, and (2) that the broad spectrum of skills and perception relevant to general practice must be selectively reduced so that academic 